\title{
Relationship between Tourist Arrival and Foreign Exchange Earnings: The Case for Bangladesh
}

\author{
Most. Asikha Aktar ${ }^{1}$ \\ Md. Nazmus Sadekin ${ }^{2}$ \\ Sanjoy Kumar Saha ${ }^{3}$ \\ 1. Lecturer, Department of Economics, Kotbari, Comilla University, Bangladesh \\ Santosh, Tangail-1902, Bangladesh \\ 3. Assistant Professor, Department of Economics, Mawlana Bhashani science and Technology University, \\ Santosh, Tangail-1902, Bangladesh
} Doi:10.5901/mjss.2014.v5n16p162

\begin{abstract}
Tourism is one of the promising sectors for Bangladesh. The success of tourism is measured by the increasing number of tourist arrival and foreign exchange earnings. The purpose of this paper is to investigate the relationship between tourist arrival and foreign exchange earnings. To evaluate the nexus between these two we apply the Johansen's multivariate cointegration procedure. In this study we find that there exists long run relation between these two variables. Here, foreign exchange earnings are used to evaluate the contribution of tourism to the economic growth. Since, Bangladesh can maximize their economic benefits from tourism activity by earning more from the receiving more visitors. It implies that tourism effects economic growth positively through huge amount of foreign exchange earnings. So, the government of Bangladesh should take a long term tourism strategic plan and tourist arrival plan in order to rebound the economy of Bangladesh.
\end{abstract}

\section{Introduction}

Tourism is a leisure activity which is emerged from the movement of people to and their stay in various destinations. People often participate in tourism activity mainly for recreational purpose (Ghosh, 2001). In Tourism activity people spend both their time and money. In brief, tourism is a business which provides information, transportation, accommodation and other services to travelers (Ghosh, 2001). Tourism offers immense potentiality for employment generation, poverty alleviation and maintaining ecological balance. It is relatively a modern phenomenon which plays an intense important role in the economic development of any country.

Generally Economic growth rate is considered as the main indicator for measuring the welfare of a country and there exists a positive relationship between these two components (Nissan et al, 2010). So policy makers are very much interested to improve those sectors that will increase economic growth rate which ultimately help to promote the welfare. Many studies have emerged that tourism is one of the most important growing sector to promote the economic growth rate of a country. The development role of tourism was first argued early in the 1970s (Harrison and Schipani, 2007). The positive economic impacts of tourism are commonly listed as increased foreign exchange earnings, increased income, and increased employment in destination areas (WTO, 1996; Lundberg et al, 1995). In the year 1999 it is estimated that approximately $\$ 700$ million, resulting in over $\$ 500$ billion in tourist receipts (Edgell, 1999) and tourism sector generates nearly 250 million jobs worldwide (WTO, 1999). In modern days tourism is one of the fastest growing and single largest industries in the world (World Travel \& Tourism Council, 2011). The contribution of tourism industry in the global as well as individual perspective is really amazing. Many countries of the world at present depend mainly on tourism as a major source of foreign exchange earnings. According to World Tourist Organization (WTO) a total number of 763 million international tourists traffic in 2004 which is $10.58 \%$ higher than previous year and earned US\$ 623 billion which shows an increase of $18.89 \%$ over 2003 . Tourism continues to surge as a world economic force, contributing nearly $\$ 5.5$ trillion to the world's economy in 2004 (WTO, 2005). In 2005, the world tourist arrivals rose to 808 million and it is expected that the volume of tourists will reach 1561.1 million in 2020. Today most of the countries in the world are trying to promote tourism sector as a major source of income and thus important means for national economic development.

In developing countries like Bangladesh tourism has become a very important and dynamic sector. The role of international tourism in generating economic benefits has long been recognized in many developing countries (Jenkins, 
1991; WTO, 1994). It is mainly because the growth of tourism sector affects not only the activities directly linked to tourism but also with other sectors. In developed countries tourism regarded as mainly a social activity with economic consequences but in developing countries it is largely an economic activity with social consequences (Jenkins, 1980). For developing countries the potential economic benefits of tourism are a major attraction. It is due to three pro-tourism arguments (Mill and Morrison, 1999). First, the increasing trend in demand for international travel due to the economic constancy and travel preference of people in developed regions. Second, the income elasticity of demand for tourism which means that as the household income of people in the developed world increases then more disposable income will be directed towards travel. Third, to support their economic development initiatives and to satisfy the demands of their own residents, developing countries are in need of foreign exchange earnings.

According to Bangladesh Economic Review (2010) Bangladesh has basically three sectors of generating revenue: Industry, Agriculture and Service. Tourism is a part of service sector which is contributing a major part of total GDP of Bangladesh. Tourism is a promising sector in Bangladesh having steady growth rate of around $13 \%$. Moreover World Travel \& Tourism Council (2011) claimed that the direct contribution of Travel \& Tourism to GDP is expected to be BDT 184.4bn (2.3\% of total GDP) in 2011, rising by 6.3\% p.a. to BDT 339.2bn (2.3\%) in 2021 (in constant 2011 prices). To maintain a sustainable growth in tourism, its present contribution and future prospects could be experienced. The tourism industry is frequently referenced in Bangladesh as a highly important stakeholder with the potential to provide extensive benefits to the economy but the success of tourism is predominately measured by the increasing number of tourist arrival and foreign exchange earnings which is used as the useful component for assessing the positive impact of tourism more or less depends on this tourist arrival both at the national and international scale. Tourism is one of the most promising sector only through which it is possible to earn millions of dollars by attracting thousands of visitors. There exists a longrun equilibrium relationship between tourist arrival and foreign exchange earnings. In this study an attempt is made to evaluate the linkage between tourist arrival and foreign exchange earnings of Bangladesh.

The remainder of the paper is organized as follows: In section 2 we briefly discuss the analytical framework of the study. Section 3 provides the test results, and finally, Section 4 presents the concluding remarks.

\section{Analytical Framework}

\subsection{Data and Econometric analysis}

We use monthly time series data of tourist arrival and foreign exchange earnings of Bangladesh for the period of 2004 to 2010. These data were obtained from the Bangladesh Parjatan Corporation and Bangladesh Tourism Board. To evaluate the linkage between arrival and foreign exchange earnings we apply the Johansen's multivariate cointegration procedure. This procedure is used because using this procedure it is easy to estimate the long-run equilibrium relationship between variables. On the other hand Eagle and Granger (1987), Enders (1995) pointed out that when the variables are nonstationary then conventional econometric technique may not be appropriate. So it is important to test stationarity of time series data to set up an appropriate methodology. Before testing the long-run equilibrium relationship between tourist arrival and foreign exchange earnings the Augmented Dickey-Fuller (Dickey and Fuller, 1981) test was used to identify the presence of a unit root for all study variables. Result of ADF test for stationarity is reported in Table-1.

It can be seen from Table-1 that for levels the null hypothesis of unit root for both variables against the alternative of stationarity is rejected both with a trend and intercept case but without a trend and intercept case the null hypothesis of tourist arrival is rejected at the $5 \%$ level but cannot be rejected at the $1 \%$ level. On the other hand, The null hypothesis for the foreign exchange earnings cannot be rejected both at the $5 \%$ and $1 \%$ level of significance without a trend and intercept case. For that we cannot clearly say that the series is stationary. But in first difference the null hypothesis of unit root for both variables is rejected in both with and without a trend and intercepts case. This implies that time series data of tourist arrival and foreign exchange earnings are integrated in the same order 1, I (1). According to Engle and Granger (1987) when the two non-stationary variables are integrated in the same order then they are cointegrated if one or more linear combinations exist between them are stationary. When the two variables are cointegrated, there is a long-run relationship. So to estimate the long run equilibrium relationship for the study we can be preceded using the cointegration technique.

\subsection{Cointegration Test}

Johansen's methodology takes the vector autoregression (VAR) of order $\rho$ as its starting point which is given by-

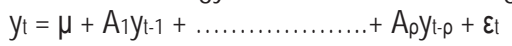


Where $y_{t}$ is an ( $\left.n \times 1\right)$ vector of variables that are integrated of order one-commonly denoted I (1) and $\varepsilon$ t is an ( $\mathrm{n} x$ 1) vector of innovations.

This VAR can be rewritten as-

$$
\begin{aligned}
& \Delta \mathrm{y}_{\mathrm{t}}=\mu+\Pi \mathrm{y} \mathrm{t}-1+\sum_{i=1}^{\rho-1} \Gamma \mathrm{i} \Delta \mathrm{yt}-\mathrm{i}+\varepsilon \mathrm{t} \\
& \text { Where, } \\
& \Pi=\sum_{i=1}^{\rho} \mathrm{Ai}-\mathrm{I} \text { and } \Gamma_{\mathrm{i}}=-\sum_{j=i+1}^{\rho} \mathrm{Aj}
\end{aligned}
$$

$\Delta$ denotes the first difference operator, $\mu$ is the intercept term and $\varepsilon_{t}$ is white noise.

If the coefficient matrix $\Pi$ has reduced rank $r<n$, then there exists $(n \times r)$ matrics $a$ and $B$ each with rank $r$ such that $\Pi=\alpha \beta^{\prime}$ and $\beta^{\prime} y t$ is stationary. Here, $r$ is the number of cointegrating relationships, the elements of $a$ is known as the adjustment parameters in the vector error correction model and each column of $B$ is a cointegrating vector. For a given $r$, the maximum likelihood estimator of $\beta$ defines the combination of $\mathrm{y}_{\mathrm{t}-1}$ that yields the r largest canonical correlations of $\Delta \mathrm{y}_{\mathrm{t}}$ with $\mathrm{yt}_{\mathrm{t}-1}$.

Johansen proposes two different likelihood ratio test, the trace test and maximum eigenvalue test, which are shown in the equation (4) and (5)

$$
\begin{aligned}
& \mathrm{J}_{\text {trace }}=-\mathrm{T} \sum_{i=r+1}^{n} \operatorname{In}\left(I-\mathrm{K}_{\mathrm{i}}\right) \\
& \mathrm{J}_{\max }=-\mathrm{T} \ln \left(\mathrm{I}-\mathrm{K}_{\mathrm{r}+1}\right)
\end{aligned}
$$

Here, $T$ is the sample size and $K_{i}$ is the $i^{\text {th }}$ largest canonical correlation. The trace test tests the null hypothesis of $r$ cointegrating vectors against the alternative hypothesis of $n$ cointegrating vectors. The maximum eigen value test tests the null hypothesis of $r$ cointegrating vectors against the alternative hypothesis of $r+1$ cointegrating vectors.

\section{Cointegration Results and Discussion}

The maximum likelihood estimation method of Johansen and Juselius (1990) is used to test for cointegration. Johansen's multivariate cointegration procedure provides two likelihood ratio tests, a trace test and a maximum eigenvalue test which indicate the cointegration status among the variables and the number of cointegration vector. Table 2 shows results of the cointegration test between tourist arrival and foreign exchange earnings. When the trace statistics and maximum eigenvalue statistics are greater than the critical values then the null hypothesis of $r$ cointegrating vectors against the alternative of $r+1$ vectors is rejected. It indicates the existence of cointegrating relationship among these two variables both at $5 \%$ and $1 \%$ level of significance. According this result we can conclude the long run stability among these two variables.

A lot of study has been conducted on the economic impact of tourism. Major economic benefits derived from the tourism activity are foreign exchange earnings, employments and income (Archer, 1995; Belisle and Hoy, 1980; Davis et al., 1988; Durbarry, 2002; Khan et al., 1990; Mill and Morrison, 2002; Uysal and Gitelson, 1994; West, 1993). We expected empirical results of this study to similar of H.J. Kim et al. (2006) who indicates a long-run equilibrium relationship between tourism and economic growth in case of Taiwan. Like Taiwan, this study found a long-run equilibrium relationship between tourist arrival (as a proxy of tourism) and foreign exchange earnings. Here the variable foreign exchange earnings is used to evaluate the contribution of tourism to economic growth. Since developing country like Bangladesh can maximize their economic benefits from tourism activity by earning more money from the receiving more visitors. It implies that tourism effects economic growth positively through huge amount of foreign exchange earnings. So due to the long-run relationship between tourist arrival and foreign exchange earnings government of Bangladesh should take a long term tourism strategic plan and tourist arrival plan in order to rebound the economy of Bangladesh

\section{Concluding Remarks}

Since tourism is a profitable sector, in the long run, sustainable tourism development in the country may be possible through adopting appropriate policies and strategies, knowledge sharing and cooperation. To expand tourism, new destinations based on regional settings should be identified and preserved for developing attractive tourism sites both for domestic and foreign tourists. Such places should be kept free from any illegal encroachment, chaos and pollution. The success of tourism development depends on the cooperation of various players involved in the sector from public and private sectors. Finally, it is already found that there exists a long run relationship between tourist arrival and foreign exchange earnings. So, it can be contribute further by creating more employment, generating demand for accommodation and food, improving transportation and as whole branding Bangladesh to the world. This is a big sub- 
sector of the national economy. There is a good research scope on country branding and the tourism.

\section{References}

Archer, B. (1995). Importance of tourism for the economy of Bermuda. Annals of Tourism Research, 22(4): 918-930.

Belisle, F.J. and Hoy, D.R. (1980). The perceived impact of tourism by residents. Annals of Tourism Research, 7(1): 83-101.

Davis et al., (1988). Segmenting local residents by their attitudes, interest, and opinions toward tourism. Journal of Travel Research, 27(2): 2-8.

Durbarry, R. (2002). The economic contribution of tourism in Mauritius. Annals of Tourism Research, 29(3): 862-865.

Edgell, D.L. (1999). Tourism Policy: The Next Millennium. Advances in Tourism Application Series. Sagamore Publishing.

Ghosh, B. (2001). Tourism and Travel Management. New Delhi: Vikas Publishing House Pvt. Ltd.

Harrison, D. and Schipani, S. (2007). Lao Tourism and Poverty Alleviation: Community Based Tourism and the Private Sector. Current Issues in Tourism, 10(2\&3): 194-230.

H.J. Kim et al. (2006). Tourism expansion and economic development: The case of Taiwan. Tourism management, 27: 925-933

Jenkins, C.L. (1980). Developing Tourism Destinations, Policies and Perspectives. Longman, Harlow.

Jenkins, C.L. (1991). Tourism policies in developing countries, in Medlik, S. (ed) Managing Tourism, pp.269-78. Oxford :Butterworth-Heinemann.

Johansens, S. and Juselius, K. (1990). Maximum likelihood estimation and inference on cointegration with application to the demand for money. Oxford Bulletin of Economics and Statistics, 52: 169-209.

Khan et al., (1990). Tourism multiplier effects on Singapore. Annals of Tourism Research, 17(3): 408-418.

Lundberg, D. E., Stavenga, M.H. and Krishnamoorthy, M. (1995). Tourism Economics. Newyork: John Wiley \& Sons Inc.

MacKinnon, J.G. (1991). Critical values for cointegration tests, in R.F. Engle and C.W.J. Granger (ed) Long-run economic relation-ships: readings in cointegration, pp. 267-276. Oxford: Oxford University Press.

Mill, R.C. and Morrison, A.M. (1999). The Tourism System: An Introductory Text (3rd Edition) . Dubuque, lowa: Kendall/Hunt Publishing Company. Mill, R.C. and Morrison, A.M. (2002). The tourism system (4th Edition). Dubuque, lowa: Kendall / Hunt Publishing Company.

MOF (2010). Bangladesh Economic Review 2010. Ministry of Finance Division. Dhaka: Bangladesh Government Press.

Nissan E., Galindo M.A and Mendez M.T. (2011). Relationship between tourism and economic growth. The Service Industries Journal, 31(10): 1567-1572.

Uysal, M. and Gitelson, R. (1994). Assessment of economic impacts: Festivals and special events. Festival Management and Event Tourism, 2(1): 3-10.

West, G.R. (1993). Economic significance of tourism in Queensland. Annals of tourism Research, 20(3): 490-504.

World Tourism Organization (1994). WTO news, July-August-September issue.

World Tourism Organization (1996). Agenda 21 for the travel and tourism industry: Towards sustainable development. Madrid: World Tourism Organization.

World Tourism Organization (1999). WTO News, July-August-September issue.

WTO. (2005). Retrieved January 10, 2010 from http://www.unwto.org/sdt/mission/en/mission.php

World Travel and Tourism Council (2011). Travel \& Tourism Impact-Bangladesh 2011. Retrieved November 15, 2012 from http://www.wttc.org/research/economic-impact-research/country-reports/b/bangladesh

\section{Annex:}

Table: 1 Augmented Dickey-Fuller Unit Root Test

\begin{tabular}{|c|c|c|c|c|c|c|c|c|c|c|}
\hline Variables & Lags & \multicolumn{2}{|c|}{ With a trend and intercept } & \multicolumn{3}{|c|}{ With a intercept } & \multicolumn{3}{|c|}{ Without a trend and intercept } \\
\hline & & $\begin{array}{c}\text { Test } \\
\text { Statistics }\end{array}$ & $\begin{array}{c}\text { Critical } \\
\text { values at } \\
\text { the5\% level }\end{array}$ & $\begin{array}{c}\text { Critical } \\
\text { values at } \\
\text { the1\% level }\end{array}$ & $\begin{array}{c}\text { Test } \\
\text { Statistics }\end{array}$ & $\begin{array}{c}\text { Critical } \\
\text { values at } \\
\text { the5\% level }\end{array}$ & $\begin{array}{c}\text { Critical } \\
\text { values at } \\
\text { the1\% level }\end{array}$ & $\begin{array}{c}\text { Test } \\
\text { Statistics }\end{array}$ & $\begin{array}{c}\text { Critical } \\
\text { values at } \\
\text { the5\% level }\end{array}$ & $\begin{array}{c}\text { Critical } \\
\text { values at } \\
\text { the1\% level }\end{array}$ \\
\hline Tourist Arrival & 1 & -8.2063 & -3.4649 & -4.0724 & -8.1025 & -2.8968 & -3.5113 & -2.5742 & -1.9448 & -2.59347 \\
\hline $\begin{array}{c}\text { Foreign } \\
\text { Exchange } \\
\text { Earnings }\end{array}$ & 1 & -4.5807 & -3.4649 & -4.0724 & -4.2538 & -2.8968 & -3.5113 & -0.6966 & -1.9448 & -2.59312 \\
\hline $\begin{array}{c}\Delta \text { Tourist } \\
\text { Arrival }\end{array}$ & 1 & -10.446 & -3.4662 & -4.0753 & -10.514 & -2.8977 & -3.5133 & -10.581 & -1.9449 & -2.59382 \\
\hline $\begin{array}{c}\Delta \text { Foreign } \\
\text { Exchange } \\
\text { Earnings }\end{array}$ & 1 & -9.9415 & -3.4655 & -4.0739 & -9.9816 & -2.8972 & -3.5123 & -10.044 & -1.9448 & -2.59347 \\
\hline
\end{tabular}

Note: $\Delta$ First difference operator. Critical values (1\% and 5\%) are from MacKinnon (1991)

Table 2: Cointegration Test between Tourist arrival and Foreign Exchange Earnings

\begin{tabular}{|c|c|c|c|c|c|c|c|c|}
\hline $\begin{array}{c}\text { Hypothesized } \\
\text { No. of CE(s) }\end{array}$ & Eigenvalue & $\begin{array}{c}\text { Trace } \\
\text { statistics }\end{array}$ & $\begin{array}{c}\mathbf{5} \% \text { critical } \\
\text { value }\end{array}$ & $\begin{array}{c}\mathbf{1} \% \text { critical } \\
\text { value }\end{array}$ & $\begin{array}{c}\text { Hypothesized } \\
\text { No. of CE(s) }\end{array}$ & $\begin{array}{c}\text { Maximum } \\
\text { Eigenvalue }\end{array}$ & $\begin{array}{c}\mathbf{5} \% \text { critical } \\
\text { value }\end{array}$ & $\begin{array}{c}\mathbf{1} \% \text { critical } \\
\text { value }\end{array}$ \\
\hline None & 0.246464 & 39.88311 & 15.49471 & 19.93711 & None & 22.92128 & 14.26460 & 18.52001 \\
\hline At most 1 & 0.188934 & 16.96183 & 3.841466 & 6.634897 & At most 1 & 16.96183 & 3.841466 & 6.634897 \\
\hline
\end{tabular}

